\title{
Craniosynostosis, Philadelphia type
}

INSERM

\section{Source}

INSERM. (1999). Orphanet: an online rare disease and orphan drug data base.

Craniosynostosis, Philadelphia type. ORPHA:1527

Craniosynostosis, Philadelphia type is a form of syndromic craniosynostosis,

characterized by sagittal/dolichocephalic head shape with a relatively normal facial appearance and complete soft tissue syndactyly of hand and foot. Transmission is autosomal dominant with variable expression of the hand findings, and incomplete penetrance of the sagittal craniosynostosis. Craniosynostosis, Philadelphia type has been suggested to share the same etiology as syndactyly type $1 \mathrm{~A}$. 